\title{
OpenMRI 下脳外科手術におけるナビゲーションシステムの精度 および操作性向上に関する研究 \\ Accuracy Evaluation of Navigation System During Neurosurgery at Open MRI Theater and Improvement of its Maneuverability
}

\author{
長嶋義昭 ${ }^{\mathrm{a}} *$, 廣瀬佐智雄 ${ }^{\mathrm{a}}$, 鈴川浩一 ${ }^{\mathrm{b}}$, 苗村潔 ${ }^{\mathrm{c}}$, 高信英明 ${ }^{\mathrm{d}}$ \\ 村垣善浩 ${ }^{\mathrm{e}}$, 伊関洋 ${ }^{\mathrm{e}}$, 梅津光生 ${ }^{\mathrm{a}}$, 高倉公朋 ${ }^{\mathrm{e}}$ \\ ${ }^{a}$ 早稲田大学大学院理工学研究科・生命理工学専攻 ${ }^{b}$ インフォコム株式会社 \\ c 東京工科大学バイオニクス部 d 工学院大学工学部機械システム工学科 \\ e 東京女子医科大学大学院先端生命医科学研究所・先端工学外科学分野
}

Yoshiaki Nagashima ${ }^{a}$, Satio Hirose ${ }^{a}$, Kouichi Suzukawa ${ }^{b}$, Kiyoshi Naemura ${ }^{c}$, Hideaki Takanobu ${ }^{d}$, Yoshihiro Muragaki ${ }^{e}$, Hiroshi Iseki ${ }^{e}$, Mituo Umezu $^{a}$, Kintomo Takakura ${ }^{e}$

${ }^{a}$ Department Integrative Bioscience and Biomedical Engineering, Waseda University

${ }^{\mathrm{b}}$ Infocom Co. Ltd cSchool of Bionics, Tokyo University of Technology

d Department of echanical Systems Engineering, Kogakuin University

${ }^{\circ}$ Faculty of Advanced Techno-Surgery, Institute of Advanced Biomedical Engineering \& Science, Tokyo Women's Medical University
Abstract
The reflective ball marker has the combined function of conventional operation marker with function of reflective ball can be recognized by optical position measuring equipment. Then, automatic registration became possible to elimi- nate artificial operation. Consequently, preparation time was decreases, and accuracy became much improved.
Key words
Reflective ball marker, Automatic registration, Preparation time, accuracy.

\section{1.はじめに}

\section{1 背景}
東京女子医科大学の脳外科手術では，手術室に OpenMRI（日立メディコ製 AIRIS II）を導入したこ とで術中画像の取得が可能となり，さらにナビゲー
* 早稲田大学院理工学研究科生命理工学専攻梅津研究室 ₹ 169-8555 新宿区大久保 3-4-1
umezu@waseda.jp
受付 2003 年 12 月 1 日；採択 2004 年 2 月 27 日
ションシステムと併用することで腫瘍摘出率が飛躍 的に向上した ${ }^{1)}$. このナビゲーションシステムは光 学式カメラ（NDI 社製ポラリス）が搭載されており, 患者頭部に設置したマーカを用いて画像一患者空間の レジストレーションを行なっている．このマーカ位 置がレジストレーション後にずれると，ナビゲーシ ヨンの精度に問題が生じる ${ }^{2334)}$. 当初ドーナツ型のマ 一カ（マルチモダリティマーカ；千代田テクノル) を患者皮膚に貼り付けていたが，術中に皮膚が動い てしまい, マーカ位置のナビゲーション誤差が $3 \mathrm{~mm}$ を超える場合はナビゲーションの使用を中断してい た。そこでマーカ位置が動かないように，開頭した 
領域の骨上に設置できるようなマーカが開発され， 現在ではマーカ位置でのナビゲーションシステムの 誤差を $1 \mathrm{~mm}$ 以下まで目指せるようになった ${ }^{5}$.

現状のレジストレーション方法の操作性および精 度に関する問題点として下記が挙げられる。 操作性の問題点 :

(1) マーカ画像（ $\phi 5 \mathrm{~mm}$ の球）がノイズと間違えや すく, また皮膚と近接した位置に貼り付けた時にマ 一カと判断しにくく, 画像からのマーカ探索が困難 な場合がある。

(2) レジストレーション時に, 骨に設置した複数個 のマーカと画像上マーカとの位置の対応が判断しに くく, マーカの番号付け（マーキング）をやり直す 場合がある。

(3) 画像からのマーカの探索や番号付け, レジスト レーション作業に $5 \sim 30$ 分近くかかることがあり, 手術の妨げになる場合がある.

誤差の問題点：

(1) 画像からマーカを探索するときに，正しいマー カ中心位置からずれたところを登録してしまう。

(2) 術者が患者上のマーカをポラリスで認識できる ポインタ（Fig. 1）で指すときに，マーカの中心から ずれたところを指してしまう。

\section{2 研究目的}

レジストレーション時の人の操作に起因する操作 性および精度に関する問題を軽減させることを目的 とする。その方策としてマーキングおよびレジスト レーション作業をハードウェア・ソフトウェアによ って自動化する機能（反射球マーカおよび自動レジ ストレーション) の開発および評価を行なう。
The reflective ball

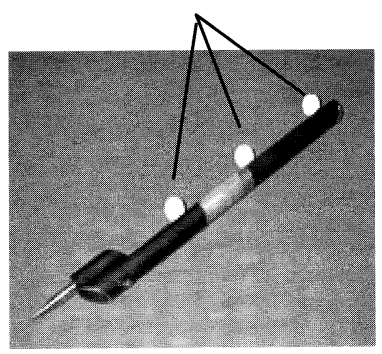

(a) pointer

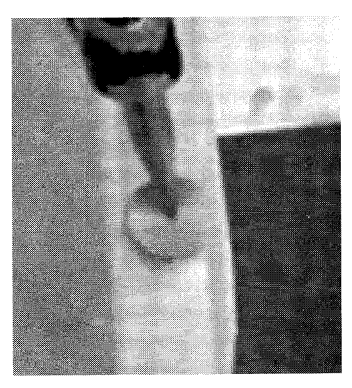

(b) Pointed out the marker
Fig. 1 pointer.

\section{2. 反射球マーカおよび自動レジストレーシ ヨン機能の構成}

\section{1 要求仕様}

2.1.1 ナビゲーションシステムの構成

東京女子医科大学で使用しているナビゲーション システムはソフトウェアを実装するためのパーソナ ルコンピュータ (PC), 撮影画像の表示を行なら表 示装置, 患者上で術者が示した位置を計測するため の光学式位置計測装置（NDI 社製ポラリス）で構成 されている。これらは運搬台に設置し一体化してい る (Fig. 2).

また, 光学式位置計測装置で位置を計測するため に術者が使用するポインタやレジストレーションを するための患者に設置するマーカ（Fig. 3）がシステ ムの主な構成である。

ポインタには位置計測用反射球（3 個）が付いて おり, 光学式位置計測装置から発した光が反射して 再びカメラが受け取ることによって位置計測用反射 球の位置を求めている.

東京女子医科大学の脳腫瘍摘出手術で使用してい るマーカは, 中に直径 $5 \mathrm{~mm}$ の球状のゲル状造影剂 が封入されており, 術野付近の頭蓋骨に設置し MRI

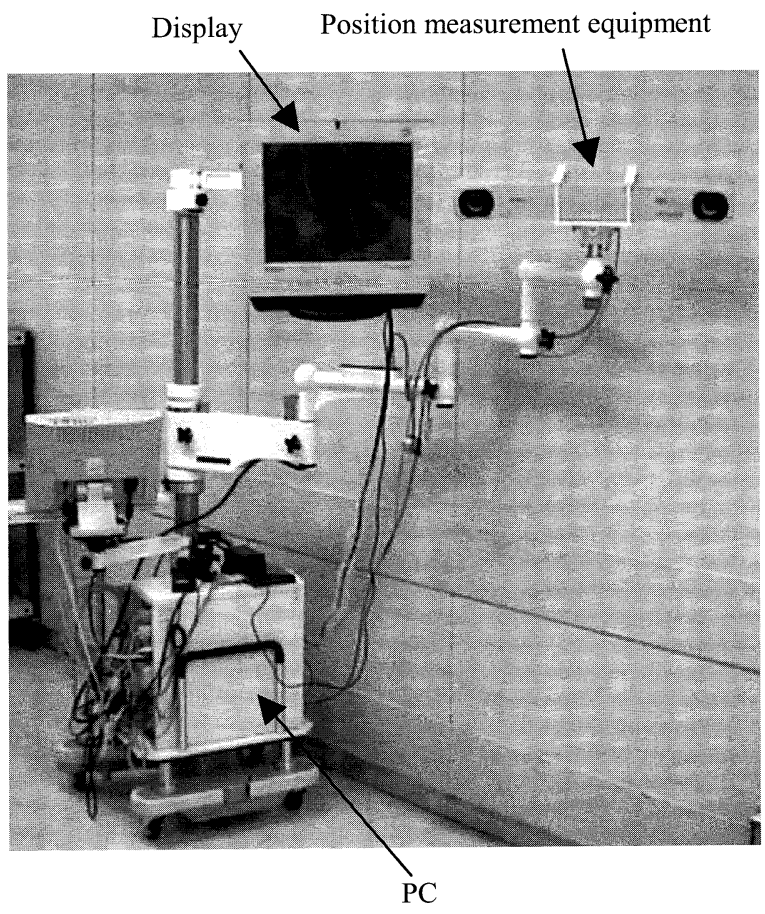

Fig. 2 Navigation system. 
撮影（Fig. 3 破線丸）を行なうと撮影画像にはマーカ が円形に映る. Fig. 3(a)の丸で囲ったものが球状の マーカである。

\subsection{2 反射球マーカ設計コンゼプト}

マーカとして，以下の条件を満たす必要がある.

(1) 内側に造影剤を入れる球形の空洞を設ける.

(2) 位置計測用反射球の機能として, 以下の条件を 満たす。

a. 直径を位置計測用反射球と同じ $11.04 \mathrm{~mm}$ とする

b. 外側に反射膜を配置する

c. 光学式位置計測装置で使用が可能

(3) マーカの中心位置と反射球の中心位置を使って レジストレーションを行ならため, 反射球マーカ の中心位置と空洞の中心位置を一致させる.

(4) 射球マーカを患者に設置してMRI 撮影を行なら ため, 非磁性体の材料を使用する。

\section{2 反射球マーカ}

仕様を満たすよう下記の通り設計した（Fig. 4).

（1）反射球マーカの樹脂ベース

反射球マーカの外形は, 反射球と同じ外形とした ( $\phi 11.04 \mathrm{~mm}$ の球体). 球形の空洞の大きさは, 現在 東京女子医科大学のナビゲーション手術で使用され ているマーカが直径 $5.0 \mathrm{~mm}$ なので, MRI の撮影画 像上でのマーカ確認を容易とするため直径 $8.0 \mathrm{~mm}$ と した。液状造影剤を中に入れるための注入口を設け た.

\section{(2) 反射膜}

反射球マーカの樹脂ベースのまわりに光学式位置 計測装置で認識可能な反射膜を貼り付けた。

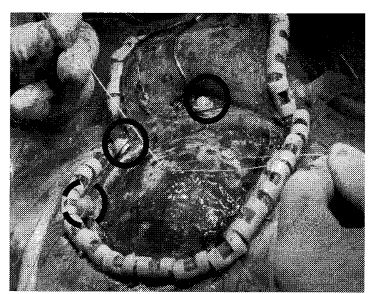

(a) The marker installed in the patient head

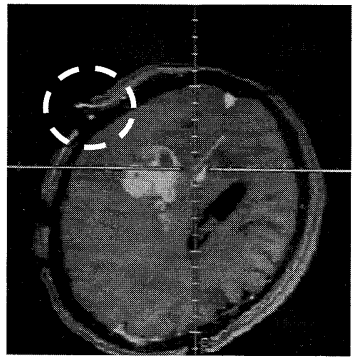

(b) MRI photography picture

Fig. 3 The marker and photography picture which were installed in the patient head.

\section{3 自動レジストレーション}

2.3.1 画像からのマーカ自動探索

（1）三次元ラベリング方による領域抽出

画像からマーカを自動抽出するために, 画像上の マーカの画素值から画像の 2 值化によって領域の抽 出を行ない, 次に三次元ラベリング方により領域の ラベル付けを行なうことにしている。
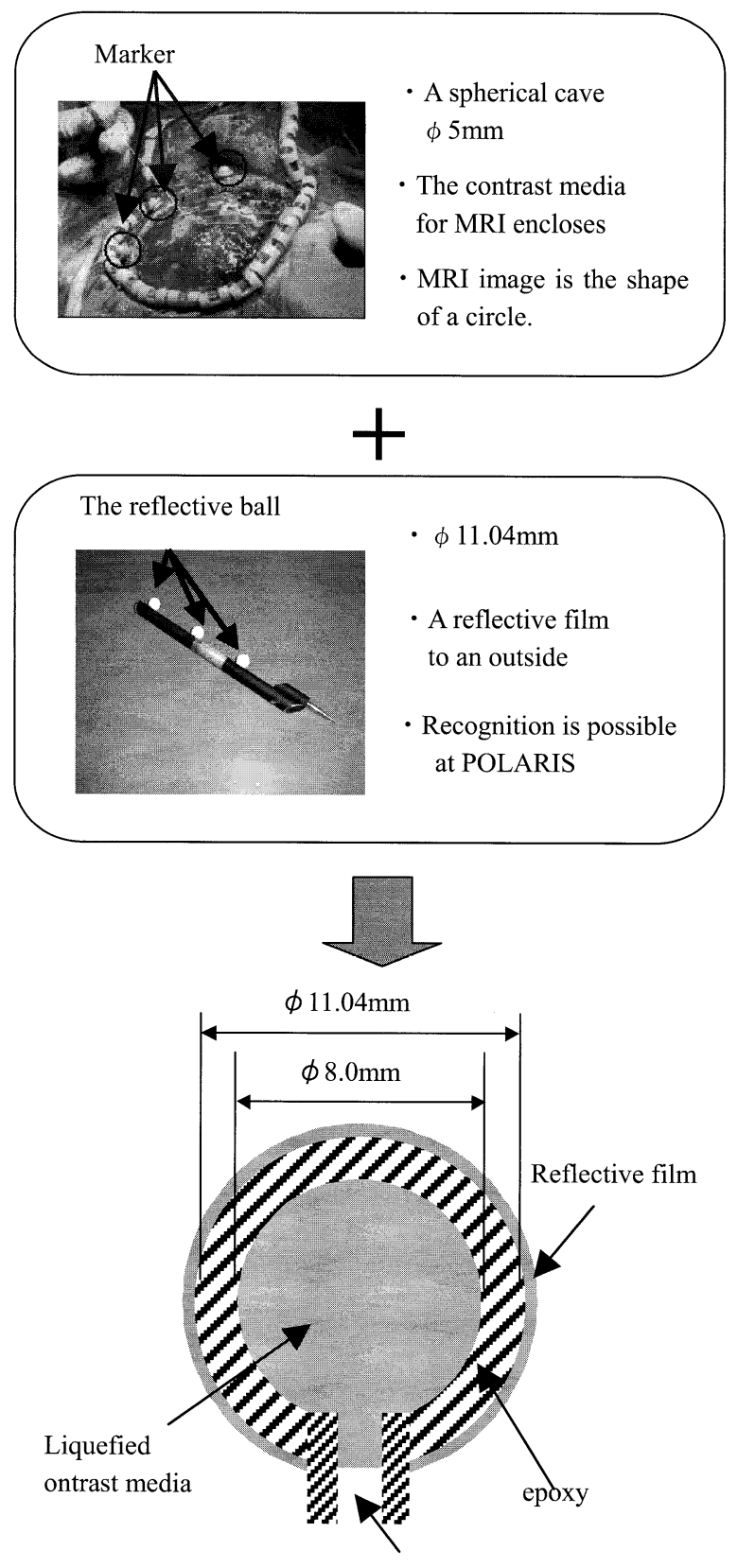

Contrast media pouring mouth

Fig. 4 Structure of reflective ball marker. 
（2）体積・形状による領域のふるい分け

次に, 三次元ラベリング方により抽出した領域か らマーカであると思われるものを，領域の体積や形 状によりふるい分けている。

i）体積によるふるい分け

体積によるふるい分けでは反射球マーカの空洞 (直 径 $8.0 \mathrm{~mm}$ ）の体積の 0.5 倍から 1.5 倍の範囲に含ま れるものをマーカと判断している.

ii）形状によるふるい分け

体積によるふるい分けでは細長い領域や平たい領 域をマーカとして判断してしまうため，領域の X 軸 方向の長さ, Y 軸方向の長さ, $\mathrm{Z}$ 軸方向の長さを求め, この長さが反射球マーカの空洞の直径 0.5 倍から 1.5 倍の範囲に含まれるものをマーカと判断している (0.5 1.5 倍の範囲は, ほぼ毎回探索が成功する值 を試行錯誤的に導出した).

(3) 領域の重心の計算

次にふるい分けによりマーカと判断した各領域に 対して重心を計算し，その位置をマーカ位置として いる。

2.3.2 自動レジストレーション

（1）患者上のマーカ位置自動探索

マーカに備えた位置計測用反射球の機能を使うこ とで, 位置計測装置から各反射球マーカの中心位置 を自動的に取得できるようになっている.

(2) 自動レジストレーション

i）画像上のマーカ位置と位置計測装置により取得し た患者上のマーカ位置を使用して，患者空間から画 像空間への写像関数を求めている. 患者上のマーカ の位置を $P_{i}$ ( $i=1$ 〜マーカ数 $)$, 画像上のマーカの 位置を $Q_{i}(i=1$ 〜マーカ数）としたとき,

$$
\sum_{i}\left|f\left(p_{i}\right)-Q_{i}\right|(|a| \text { は } a \text { の長さ })
$$

を最小とする関数 $f$ が求めるべき写像関数である.

ii）誤差計算アルゴリズム

ナビゲーションシステムの誤差として平均誤差・ 最大誤差を表示している，特にナビゲーションシス テムの精度を示すときは最大誤差を使用している。

患者空間から画像空間への写像関数を $f$, 患者上の マーカの位置を $P_{i}(i=1 \sim$ マ $(i$ 数 $)$, 画像上のマ 一カの位置を $Q_{i}(i=1$ 〜マーカ数 $)$ としたとき,

$$
\begin{aligned}
& \text { 平均誤差 }=\sum_{i}\left|f\left(p_{i}\right)-Q_{i}\right| \\
& \text { 最大誤差 }=\max \left(\left|f\left(p_{i}\right)-Q_{i}\right|\right)
\end{aligned}
$$$$
\text { と定義している. }
$$

\section{3. ナビゲーションシステムの操作性評価}

\section{1 反射球マーカおよび自動レジストレーショ機能 動作確認}

3.1.1 方法

健常成人男子 6 名（平均年齢 30 歳）に実験の主旨 を口頭および文書で説明した上で了承を得て，それ ぞれの頭部に反射球マーカを 3 個設置した台座 $(6.0$ $\times 5.0 \times 1.0 \mathrm{~cm}$ のアクリル板）を取り付け，MRI 撮 影を行なった（Fig. 5).

それぞれの頭部画像に対して, 自動マーカ探索, 自動レジストレーション，およびナビゲーションを 行なった。

\section{1 .2 実験結果}

自動マーカ探索の実験結果を Table 1 亿示す．被 験者 $\mathrm{A}, \mathrm{B}, \mathrm{C}$ については 3 個のマーカを自動探索でき た。正しく探索できたマーカは Fig. 6 に示すように 画像上で円状に映っている．白い破線丸で囲ってい るものがマーカである。

しかし，被験者 D では 2 個のマーカしか探索でき なかった。これは，Fig. 7 に示すように久けた部分 のある撮影像であったためと考えられる。

また被験者 $\mathrm{E}$ も 2 個のマーカしか探索できなかっ た。これはFig. 8 に示すようにマーカが円状で映っ ているが，マーカの画素值に近いものがマーカに接 しているため，領域抽出のときにマーカの画素值に 比較的近いものがマーカと一体となって抽出され,

Table 1 Automatic marker search result.

\begin{tabular}{c|c}
\hline \hline Subject & $\begin{array}{l}\text { The number of markers } \\
\text { for which it was searched }\end{array}$ \\
\hline A,B,C & 3 \\
\hline D,E & 2 \\
\hline F & 4 \\
\hline
\end{tabular}

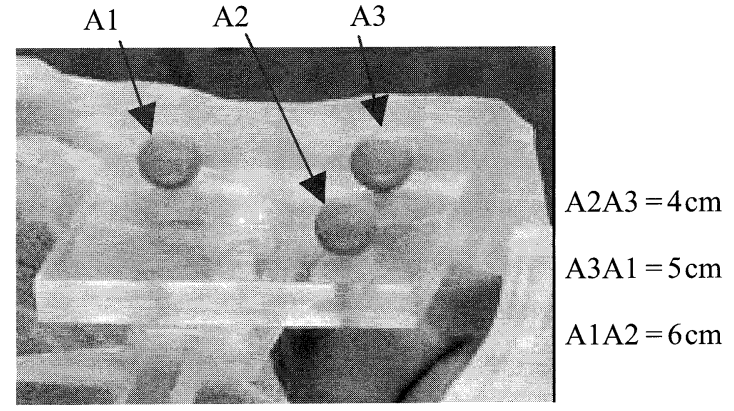

Fig. 5 Reflective ball marker installation state. 
体積でのふるい分けでマーカでないと判断されてい た。

被験者 $\mathrm{F}$ では脳の一部をマーカとして判断したが (Fig. 9)，自動レジストレーションの際に反射球マー 力の位置関係 (本実験では 4, 5, $6 \mathrm{~cm}$ の直角三角形) から画像上のマーカを決定しているため, 必要なマ 一カ探索が成功していれば，レジストレーションに 影響は無いと考えられる。本実験ではマーカと判断 した 4 つの中から $4,5,6 \mathrm{~cm}$ の三角形の位置関係にあ る 3 つのマーカの間でレジストレーションができた.

\section{1 .3 考察}

（1）反射球マーカの位置計測用反射球機能

レジストレーションにおいて反射球マーカの位置 を位置計測装置で求められたため, 反射球マーカは 位置計測用マーカとして使用できると考えられる。

（2）反射球マ一カの使用方法の検討

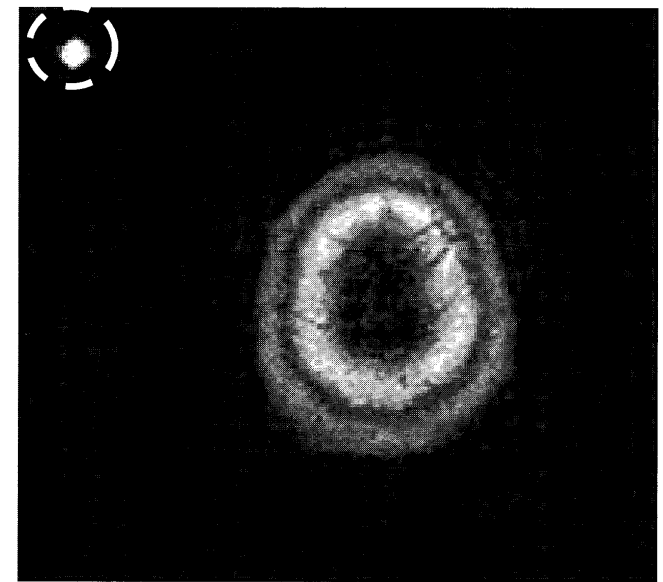

Fig. 6 A : The marker for which it has searched.

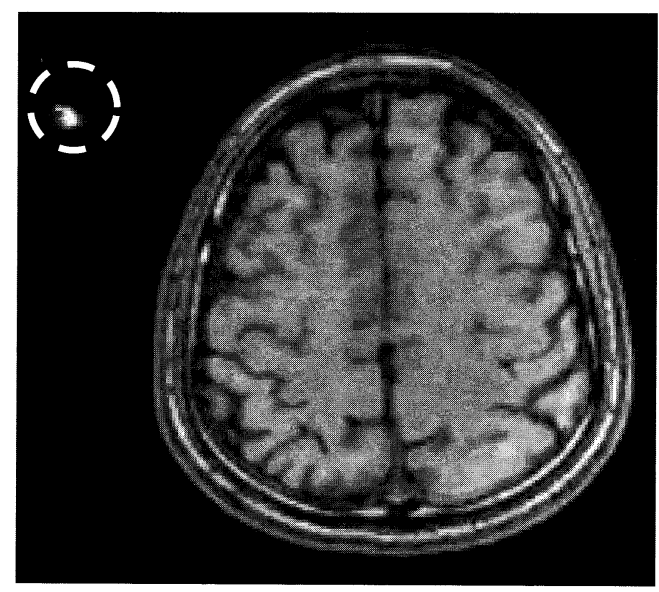

Fig. 7 D : The marker for which it has not searched.
マーカが円状に映らない原因として，造影剂の量 が少ない場合や気泡，ゴミの混入によって造影剤が 反射球マーカの球状の空洞全体に注入されていない 場合があった。 また造影剤の注入を繰り返すうちに， 中に残った少量の造影剤が乾燥し，固まって中にこ びりついてしまう問題が生じた（Fig. 10）。解決策と しては，液状造影剤を毎回注入する構造から，ゲル 状造影剤をあらかじめ密封しておく構造に変更する ことで，常に同じ形状の撮影像を得られるようにす ることを考えている。

\section{2 ナビゲーション準備時間の測定}

\subsection{1 方法}

手術マーカと反射球マーカに対してナビゲーショ ン準備時間（MRI 画像からのマーカ探索十マーキン グ作業 +レジストレーション作業にかかった時間)

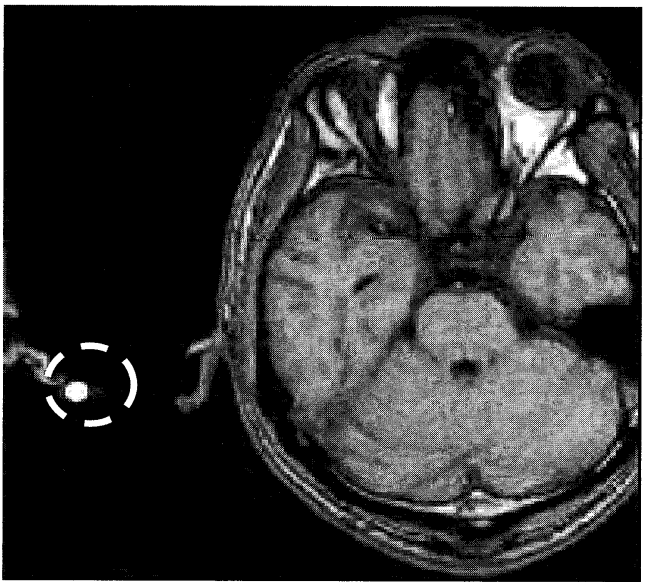

Fig. 8 E : The marker for which it has not searched.

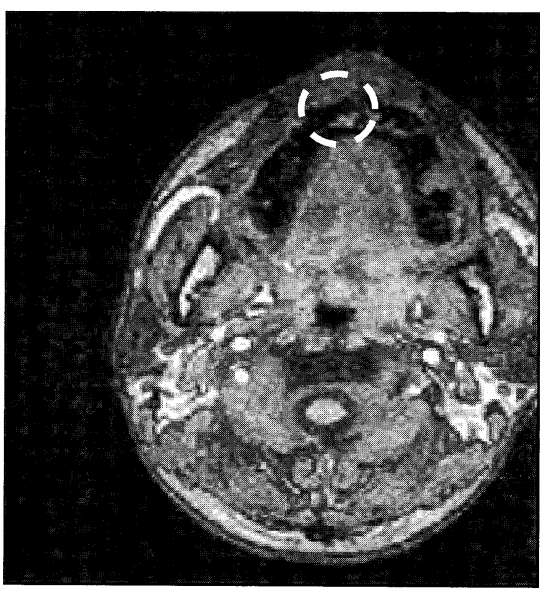

Fig. 9 F : A brain is judged to be a marker. 
を Fig. 11 の状態で測定する.

\section{2 .2 実験結果および考察}

ナビゲーション準備時間の測定結果を Table 2 に 示す。手術マーカを使用した場合は 120 秒かかった のに対し，反射球マーカを使用した場合は約 50 秒で あった。画像からのマーカ探索拉よび患者上のマー カ位置の検出・レジストレーションを自動的に行な うため，人による作業が減少し操作性向上が図れた と判断できる.

\section{4 ナビゲーションシステムの精度評価}

手術マーカと反射球マーカの精度に関する評価を 行ない，反射球マーカを用いることでどれだけ精度 が向上するか検討する.

\section{1 手術マーカと反射球マーカの製作精度}

手術マーカおよび反射球マーカの製作方法, 材質, 製作誤差は下記(1)，(2)の通りである.

(1)手術マーカ（撮影用とレジストレーション用）

製作方法：切削

材質：ポリイアミド

製作誤差 : $0.2 \mathrm{~mm}$ 以内

(2)反射球マーカ

製作方法：光造形

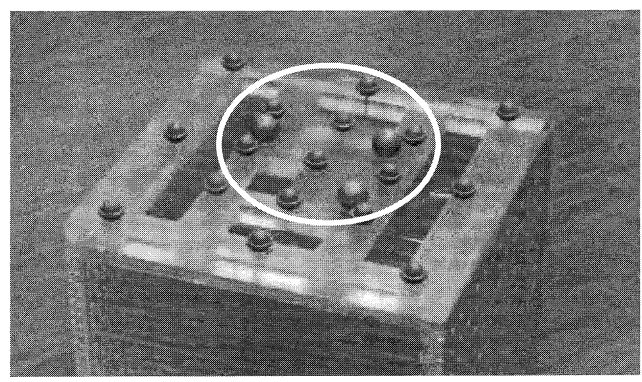

(a) CT photography state
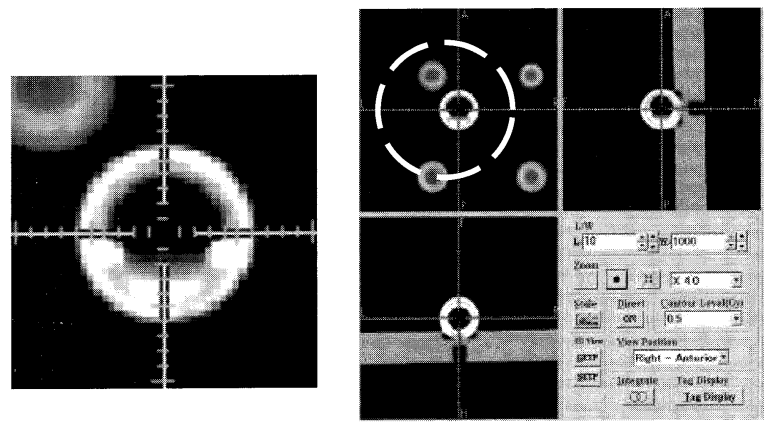

(b) CT photography picture

Fig. 10 Dirt inside a reflective ball marker.
Table 2 Navigation preparation time measurement result.

\begin{tabular}{c|c}
\hline \hline maeker & Preparation time (sec) \\
\hline Conventional marker & 120 \\
\hline Reflective ball marker & 48 \\
\hline
\end{tabular}

材質：アクリル・エポキシ系樹脂

製作誤差 $: 0.1 \mathrm{~mm}$ 以内

マーカ個々の製作精度に関しては，差異がほとん ど無く, 反射球マーカのほうが若干（抢よそ 0.1 $\mathrm{mm}$ ）良い程度だが，手術マーカは撮影用マーカとレ ジストレーション用マーカの 2 種類（Fig. 12）を作 業ごとに付け替えるため, 最大で $0.4 \mathrm{~mm}$ 近くの誤差 が生じる可能性がある。

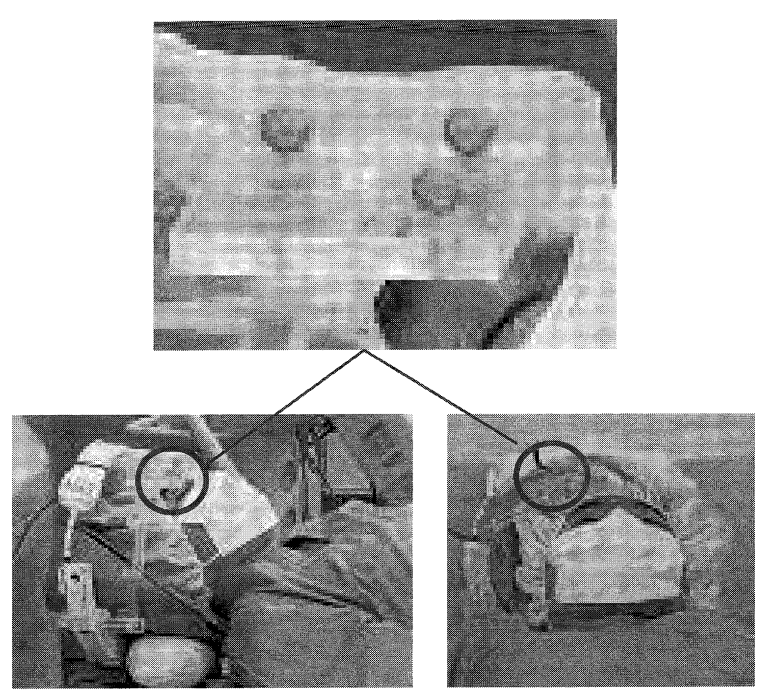

(a) Photography state
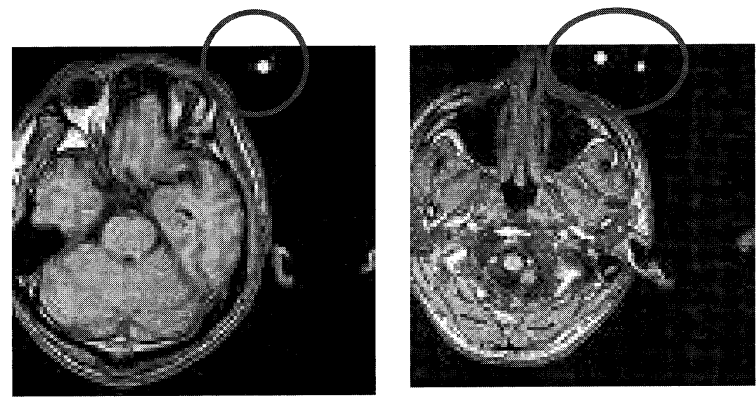

(b) MRI photography images

Fig. 11 A marker installation state and an MRI photography picture. 


\subsection{MRI 撮影画像の比較（T1/T2）}

手術マーカと反射球マーカの MRI 撮影像を Fig. 13 に示す. 手術マーカの中には直径 $5 \mathrm{~mm}$ の球形のゲ ル状造影剤が封入されており，反射球マーカの中に は液状造影剂が直径 $8 \mathrm{~mm}$ の球形に満たされるよう に設計されている，画像のコントラストをそれぞれ 調節することで，どちらも設計通りの撮影像が得ら れている(撮影像の球の直径誤差は，画像解像度約 $0.8 \mathrm{~mm} / 1$ pixel 以内である).

\section{3 ナビゲーション誤差の比較}

\subsection{1 方法}

同一平面上で $40,50,60 \mathrm{~mm}$ の三角形となるように マーカ 3 個を配置し，レジストレーションした時の ナビゲーション誤差（マーカ 3 点の画像と実際の位 置とのずれの平均值と最大值 (2.3.2(2)ii）誤差計算 アルゴリズム参照)）を20 回測定する（Fig. 14）.

本実験は，マーカ撮影および画像上のマーカ探索 作業（手術マーカは人の操作によって探索，反射球 マーカは自動探索機能使用）後，同じ登録条件を用 いてレジストレーション作業を 20 回繰り返した。

\subsection{2 結果}

測定結果（Fig. 15）より，マーカのナビゲーショ
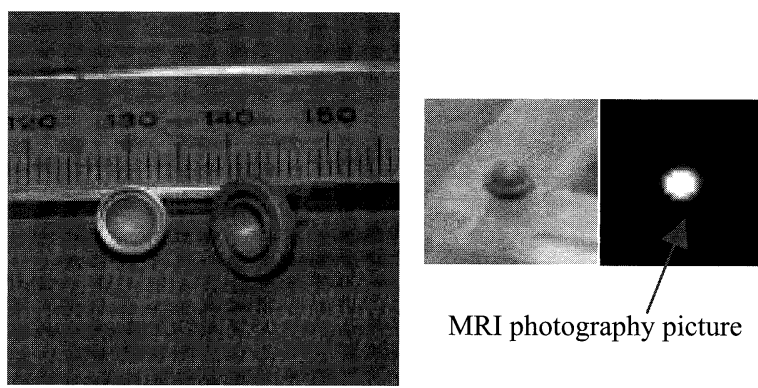

(a) The marker for photography
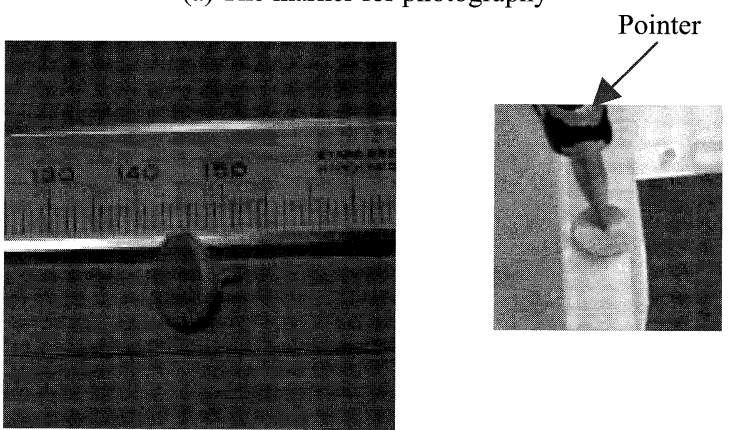

(b) The marker for registration

Fig. 12 Conventional marker.
[ウエルチの $t$ 検定 $]$

帰無仮説：マーカ間の誤差に有異差は無い

対立仮説：手術マーカは反射球マーカの誤差より大き W

統計量 $T$, 自由度 $f$, 有意確立 $p$, 有意水準 $\alpha=0.05$ 平均誤差 $(T=6.7572, f=19.0097, p=9.3370 \mathrm{E}-07)$, 最大誤差 $(T=8.1635, f=19.003, p=6.1962 \mathrm{E}-8)$ どちらも共に有意水準 $>$ 有意確立 よって帰無仮説を棄却し，対立仮説を採択 有意水準 0.05 で，手術マーカのナビゲーション誤差 は新反射球より大きいといえる.

ン誤差（20 回平均値）は, 手術マーカ：平均值 0.45 $\mathrm{mm}$, 最大值 $0.85 \mathrm{~mm}$, 反射球マ一カ : 平均值 0.24 $\mathrm{mm}$ ，最大值 $0.39 \mathrm{~mm}$ であり，反射球マーカによっ て精度が向上したといえる（20 回平均で，平均値 $0.21 \mathrm{~mm}$, 最大值 $0.46 \mathrm{~mm}$ 向上した).

\subsection{3 考察}

4.3.1 でナビゲーション誤差を 20 回測定したが, 反射球マーカは測定值のバラツキがほとんどなかっ たのに対し，手術マーカは測定值が大きくばらつい た（測定値の標準偏差は，反射球マーカ：平均値 $0.002 \mathrm{~mm}$, 最大值 $0.002 \mathrm{~mm}$, 手術マーカ: 平均値 $0.14 \mathrm{~mm}$ ，最大值 $0.251 \mathrm{~mm}$ )。測定に用いたマーカお よびマーカ撮影像は同じものを使用したので，測定 值がばらついた要因は測定ごとにポインタをマーカ に指し直したことによってポラリスとポインタの位

Scale : $1 \mathrm{~mm}$

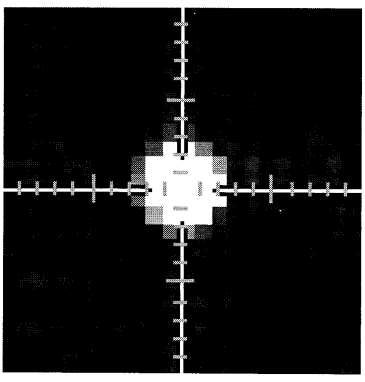

T1 image $1200 \mathrm{~L} / 2500 \mathrm{~W}$

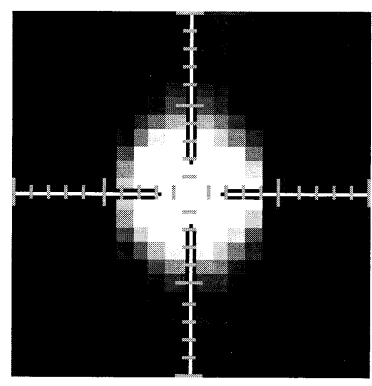

T1 image 2000L/3000W
(a)Conventional marker

Fig. 13 Marker MRI photography picture. 


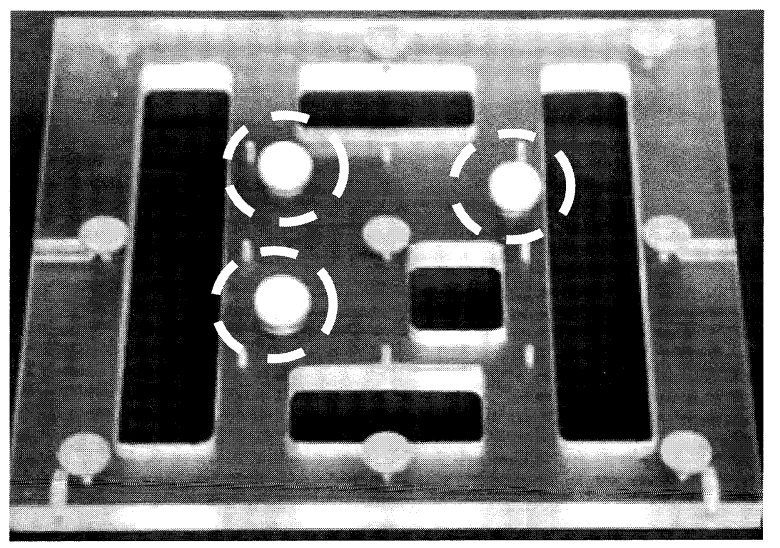

(a) Marker position

Conventional marker

Reflective ball marker

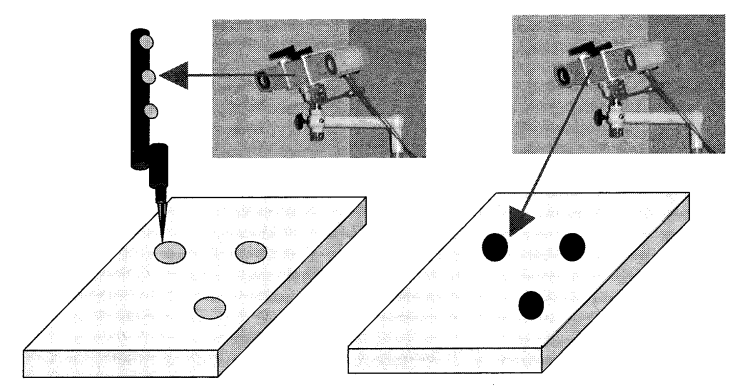

(b) Conventional marker measurement

(c) Reflective ball marker measurement

Fig. 14 Navigation accuracy measurement state.

置関係が変化したと考えられる（Fig. 14(b))。この ことから反射球マーカを用いることで, 従来のナビ ゲーションシステムに生じていた人為的な作業（ポ インタを指す作業）による誤差を無くすことができ， システムの精度を向上させることが可能と言える.

\section{5. まとめと展望}

反射球マーカおよび自動レジストレーション機能 を開発したことにより, 東京女子医科大学で現在使 用いている脳外科手術用ナビゲーションシステムの レジストレーションにかかる操作時間を短縮させ, ナビゲーション精度を向上させることが可能となっ た。またレジストレーションに必要だったポインタ がいらなくなるので, 部品点数を減らせること, マ 一カ探索作業拉よびレジストレーション作業が自動 化されるので，オペレータが初心者でも扱いやすく

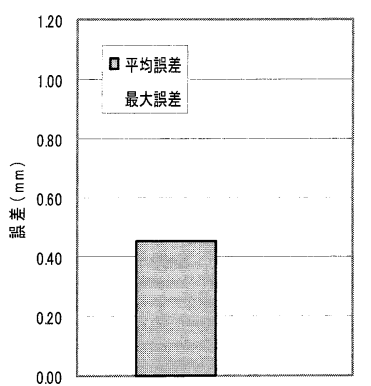

(a) Conventional marker

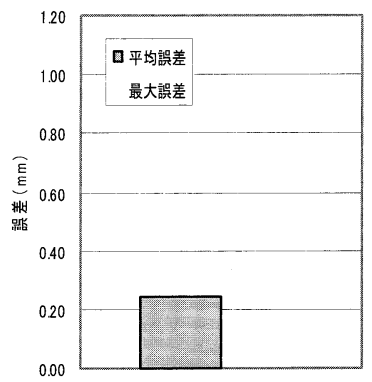

(b) Reflective ball marker
Fig. 15 Navigation error measurement result.

なるなどの利点があげられる。 また，一度レジスト レーションを行なった後にカメラないし患者を動か した場合, 従来のマーカでは患者 - 画像座標系の関 係が崩れるため再度レジストレーションを行なって いたが, 反射球マーカならばカメラが常にマーカ位 置を取得しているので, 移動後のマーカ位置から患 者 - 画像座標系の関係を回復し, ナビゲーションを 続けることが可能である.

今後は反射球マーカを実用化するためにマーカの 製造方法, 術野への実装方法について検討を進める.

謝辞: 早稲田大学と東京女子医科大学の連携大学院 による研究プロジェクトとして実施された。関係各 位に感謝する。マーカの製造には(侑)安久工機ならび に Northern Digital inc. にご協力いただいた.

\section{文献}

1) Iseki H, Muragaki $Y$, Taira $T$, Kawamata $T$, Maruyama $T$, Naemur K, Namb K, Sugiur M, Hirai N, Hori T, Takakura K. New possibilities for stereotaxis Information-guided, stereotaxis. Stereotact Funct Neurosurg 2001; 76: 159-167.

2) 余田貞人, 土屋啓. 内視鏡下副鼻腔手術ナビゲーショ ンシステムのための頭部レジストレーション精度の評 価. 医用画像工学研究会 JAMIT Frontier1999. 豊橋 : 181-186.

3) Hauser R, Westermann B, Probst R. A non-invasive patient registration and reference system for interactive localization in intranasal sinus surgery. Proc Inst Mech Eng[H] 1997; 211: 327-334.

4) Gunkel A R, Freysinger W. Three-dimensional image guided endonasal surgery with a microdebrider. Laryngoscope 1997; 107: 834-838.

5) 村垣善浩, 橋爪誠. 外科領域に於ける最近の進歩; 術 中オープン MRI とリアルタイムナビゲーション. 福岡 医学雑誌 2002; 93:223-230. 